\title{
Development of Encyclopedia Media Based on Indonesian Cultural Diversity
}

\author{
Fredy Hermanto ${ }^{1}$, Asep Ginanjar², Noviani Achmad Putri ${ }^{3}$, Elin Atikah $^{4}$, \\ Umi Dary Mu`Aafat ${ }^{5}$, Heldi Prasetya ${ }^{6}$
}

${ }^{123456}$ Faculty of Social Sciences, Universitas Negeri Semarang

\{Fredy@mail.unnes.ac.id ${ }^{1}$, asep.ginanjar@mail.unnes.ac.id ${ }^{2}$, noviani.ips@mail.unnes.ac.id ${ }^{3}$, elin.atikah80@students.unnes.ac.id ${ }^{4}$, umdr.muaafat@students.unnes.ac.id ${ }^{5}$, heldipras@ @students.unnes.ac.id $\left.{ }^{6}\right\}$

\begin{abstract}
Based on a survey of the Central Bureau of Statistics (BPS) conducted (2018) in 181 districts and 34 provinces involving 12,056 respondents found that $10 \%$ of respondents did not memorize Pancasila and only about $67-78 \%$ of respondents knew about the Unitary State of the Republic of Indonesia and Bhineka Tunggal Ika. Indonesia National Board for Disaster Management (BNPT) survey results in 2019 found that diversity education content has a low score compared to other dimensions. Education can be used as a preventive means of prevention of intolerant behaviors that are currently rife in Indonesia. The fading of the nation's cultural values among the younger generation due to the negative impact of globalization should certainly be a concern of many parties, including education. Diversity education has often been considered to interfere with the learning process in the classroom. Diversity materials can actually be integrated into materials taught in the classroom, especially in social science subjects. Problematic of learning that is still lacking in the variety of learning media and not contextual causes the material of Indonesian cultural diversity is not delivered optimally and students are not interested in learning it. Analysis conducted to teachers and students shows the need for learning media that can help teachers and students learn diversity. Researchers developed encyclopedia media as an alternative learning medium to study diversity, especially in the field of culture. This research is an Research and Development study using 4D models. The 4D development model consists of 4 main stages, namely: Define, Design, Develop and Disseminate. The media is validated by material experts and media experts to assess the feasibility of the media encyclopedia diversity, especially in the field of culture. This study examined the condition of geographic areas in each region, then identified various forms of culture. Furthermore, this study tries to explore everything about the ins and outs of philosophy or meaning and values of each existing culture. The results of this study are encyclopedia media based on Indonesian culture which includes geographical location, language, traditional house, traditional dance, traditional clothing, food, traditional tools and local traditions.
\end{abstract}

Keywords: Media development, Encyclopedia, Diversity.

\section{INTRODUCTION}

The rapid development of science and technology has an impact on various aspects of life, economy, politics, socio-culture and security of a Country. Globalization brings many universal values such as capitalism, liberalism, feminism, hedonism that can lead to the fading of Indonesian cultural values. The number of cases of promiscuity, bullying, drug abuse is evidence of the fading of Indonesian cultural values.

Based on a survey of the Central Bureau of Statistics conducted (2018) in 181 districts and 34 provinces involving 12,056 respondents, it can be known that there are $10 \%$ of people who do not memorize Pancasila and only about $67-78 \%$ of the public who know about the Unitary State of the Republic of Indonesia and Bhineka 
Tunggal Ika [1], this shows that the national insight of the community is very lacking.

The fading of the nation's cultural values in the younger generation due to the negative impact of globalization should certainly be a concern. National Education System Law No. 20 of 2003 The third article says that national education serves to develop the ability and form the character and civilization of the nation, which aims to develop the potential of learners to become human beings who are godly, noble, knowledgeable, capable, creative, independent, and become democratic and responsible citizens [2] Based on the Law, the purpose of education not only produces a generation that has knowledge, but also forms the character and character of learners to be good citizens in accordance with the personality of the Indonesian nation, Pancasila and the Constitution.

Universitas Negeri Semarang (UNNES) has since 2010 declared as a Conservation University, which means that all activities within Universitas Negeri Semarang which includes education, research, and devotion refer to conservation principles both conservation of natural resources, environment, and arts and culture. Faculty of Social Sciences as one of the faculties in UNNES also develop conservation values. Conservation developed in the FIS environment is Social Conservation based on two pillars, namely social intelligence and social wisdom. Social Conservation is developed by all study programs located in the context of the Faculty of Social Sciences, including the Social Science Education Program.

Social Science Education Program as one part of the Faculty of Social Sciences has a responsibility to produce a generation that holds the nation's cultural values so that the unbearable flow of globalization will not be able to disrupt the nation's cultural values. One of the efforts to maintain these cultural values is to study them through the Encyclopedia. The encyclopedia is derived from the Greek "encylospadea" meaning a series of facts or disciplines delivered informatively and comprehensively[3][4]. The Encyclopedia is a list of subjects (references) in which various information about their definitions, backgrounds, and bibliographic data are arranged alphabetically and systematically [5].

The Encyclopedia is a source of reference usually shown in the explanation [6]. The types of subject encyclopedias are general encyclopedia and special encyclopedias[ 7]. Based on the type of media there are print, digital, and electronic encyclopedias. Based on the length of time the users of the encyclopedia are two for adulthood and children. It can be concluded that encyclopedias are references used to add insight and contain more detailed information from learning resources used in schools. Not only in the form of writing, the encyclopedia contains various images to make the encyclopedia look interesting. Completeness of the material and the presence of several examples of images that can be observed directly by learners [8]. The Encyclopedia makes it easy for students or teachers to obtain information on materials or facts from a variety of topics required in the preparation of teaching [9].

In this case the author tries to develop a learning medium that can introduce indonesian culture to the younger generation. Culture is all the power of the mind, namely copyright, taste and initiative [10], as all the works, tastes, and copyrights of society [11]. Culture means thoughts, minds, results, customs or something that has become a habit that is difficult to change[12]. Culture includes knowledge, beliefs, art, morals, laws, customs and customs practiced by a group of members of the community [13]. Culture includes everything that human beings get or learn as members of society [14]. Culture is a way of life that develops and is shared by a group of people and passed down from generation to generation.

Indonesian culture is all national culture, local culture, and foreign culture that existed in Indonesia before Indonesia's independence in 1945. Indonesian culture can also be interpreted that Indonesia has a variety of ethnic groups and cultures such as regional dances, traditional clothing, and traditional houses. Many cultural values of the Indonesian nation are important to learn, this is because, the value can be seen as the purpose of human life itself [15] The value system that exists in a society is used as an orientation and reference in acting [16]. Meanwhile, Sumaatmadja said that in the development, development, application of culture in life, there are also inherent values in society that govern harmony, harmony, and balance [17]. Therefore, how important Indonesian cultural values are learned one of them through the media Encyclopedia of Indonesian Culture.

Encyclopedia budaya Indonesia is an encyclopedia developed based on the principles of learning media designed as interesting as possible so as to inspire the culture of the Indonesian nation from various regions more clearly. It is through this Encyclopedia that it is hoped that the message in the media can be conveyed to the reader [18], this is what makes the Encyclopedia as an introduction to the message from the sender to the recipient of the message [19]. This encyclopedia focuses on the description of traditional houses and traditional dances and the values contained in them, so that the younger generation not only know the form of traditional houses and traditional dances, but also can understand the content of philosophy and values in them. This encyclopedia can be used as a medium of learning in social science subjects in schools, as well as as reading by the general public. This article is the result of a development study aimed at developing the Indonesian Encyclopedia of Culture to instill cultural values. More specifically, the purpose of this study was to develop the 
Encyclopedia of Indonesian Culture to instill Indonesian cultural values; and review the media feasibility of the Encyclopedia of Indonesian Culture to instill Indonesian cultural values.

\section{RESEARCH METHOD}

This research is a research development. The research development model uses the 4-D model. The 4-D development model consists of 4 main stages, namely: Define, Design, Develop and Disseminate [18]. The steps are as follows:

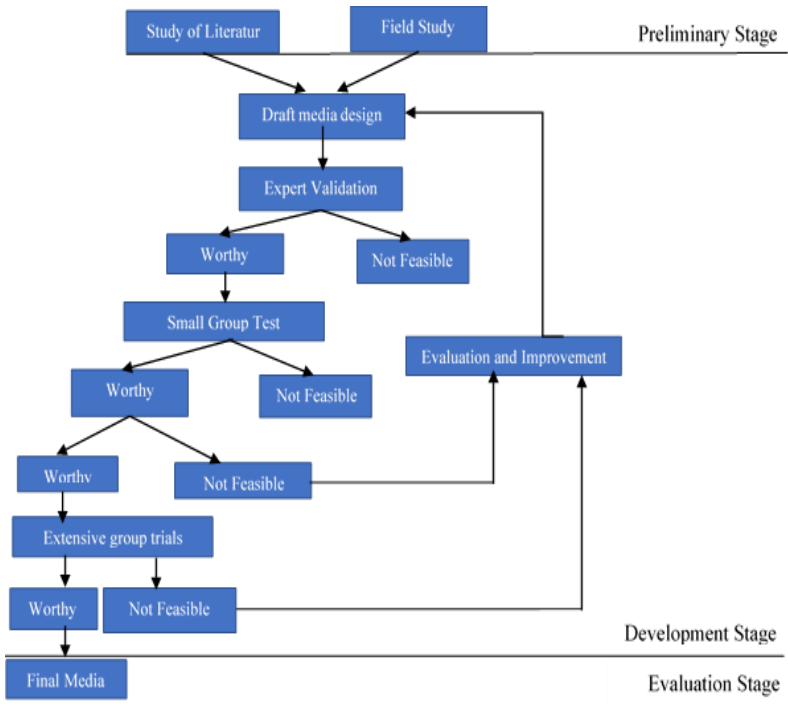

Figure 1. 4D Development Model

The first step is the define stage where the need analysis of the media encyclopedia diversity is carried out. This integrity analysis was conducted on 2 junior high schools in Semarang, namely SMP 21, SMP 19, class 7 and 8 respectively as many as 119 respondents. The next step is to design the media encyclopedia diversity, development in the form of input from material validators and media and lastly is the media encyclopedia diversity.

The feasibility evaluation by the expert uses the Likert scale to determine the media encyclopedia diversity. The variables to be measured are defined as indicator variables, then it is used as a starting point for composing instruments that are statements or questions.

\section{RESULTS AND DISCUSSION}

\subsection{Define Stages}

This stage is the first stage in this study. At this stage analysis needs to students to know their need for based Learning the media encyclopedia diversity. Based on the requirement analysis that has been done to 119 respondents obtained the following results:

\section{a. Provision of cultural diversity materials by teachers}

Based on the results of a needs analysis conducted for 119 respondents regarding the provision of cultural diversity materials by teachers, the following data are obtained:

Tabel 1. Provision of cultural diversity materials by teachers

\begin{tabular}{llll}
\hline Indicator & Yes & No & Total \\
\hline $\begin{array}{l}\text { Learn about culture with } \\
\text { your teacher }\end{array}$ & $73.1 \%$ & $26,9 \%$ & $100 \%$ \\
$\begin{array}{l}\text { Know the definition of } \\
\text { cultural diversity from }\end{array}$ & $56,3 \%$ & $43,7 \%$ & $100 \%$ \\
$\begin{array}{l}\text { teacher explanations } \\
\text { Understanding cultural } \\
\text { diversity from teacher } \\
\text { explanations }\end{array}$ & & & \\
\hline Source: Primary Data Processed, 2021 & $45,4 \%$ & $100 \%$ \\
\end{tabular}

In Table 1 there are three indicators to find the diversity of culture in the learning process in class. The first indicator students have studied cultural diversity with teachers by $73.1 \%$ and those who answered had never learned that by $26.9 \%$. Learning about diversity that has been taught is an effort to provide students with an understanding of Indonesia's diverse conditions, so knowledge, attitudes and behavior are needed that reflect tolerance for other parties. The second indicator, in the learning process, students' ability to understand the definition of cultural diversity from the teacher's explanation was only $56.3 \%$ and there were still quite a lot that did not understand the definition of cultural diversity by $43.7 \%$. Based on the second indicator, it can be seen that most students have understood the definition of diversity. In the third indicator namely students' understanding of cultural diversity based on explanations by teachers is only $54.6 \%$ and those that do not understand are $45.4 \%$. The material provided by the teacher is proven to be understood by some students based on these indicators but the difference with students who do not understand is not far away, of course this situation needs to be a concern because it needs learning methods or learning media so that students understand more about the diversity used by teachers.

b. Selection of learning resources in the form of encyclopedias

Based on the results of a needs analysis conducted for 119 respondents regarding the selection of learning resources, the following data are obtained: 
Tabel 2. Selection of encyclopedias as a source of learning

\begin{tabular}{llll}
\hline \multicolumn{1}{l}{ Indicator } & Yes & No & Total \\
& & & \\
\hline $\begin{array}{l}\text { Prefer to use } \\
\text { encyclopedias as a } \\
\text { learning resource rather } \\
\text { than textbooks }\end{array}$ & $67,2 \%$ & $32,8 \%$ & $100 \%$ \\
$\begin{array}{l}\text { Speed of understanding } \\
\text { material using } \\
\text { encyclopedias }\end{array}$ & $50,8 \%$ & $49,2 \%$ & $100 \%$ \\
\hline
\end{tabular}

Source: Primary Data Processed, 2021

Based on the data in table 2 it is known that students prefer to use encyclopedia diversity as a learning resource compared to using text books by $67.2 \%$. In using encyclopedia diversity as a source of learning, students look to understand the material faster by $50.8 \%$, although it differs slightly from those who do not understand the material quickly when learning to use encyclopedia diversity by $49.2 \%$. In both indicators, students prefer learning resources in the form of encyclopedias compared to books, because encyclopedias display more pictures than text so that they do not get bored quickly to learn and understand the material faster. Encyclopedias can be used as alternative learning resources for students to increase their interest in learning.

\section{c. Experience using encyclopedia media as a learning} resource

Based on the results of a needs analysis conducted for 119 respondents regarding the selection of learning resources, the following data are obtained:

Tabel 3. Experience using encyclopedia media as a learning resource

\begin{tabular}{llll}
\hline Indicator & Yes & No & Total \\
\hline $\begin{array}{l}\text { Have used } \\
\text { encyclopedia media as } \\
\text { a learning resource }\end{array}$ & $79 \%$ & $21 \%$ & $100 \%$ \\
$\begin{array}{l}\text { Learning with } \\
\text { encyclopedias is more } \\
\text { fun and attention- } \\
\text { grabbing }\end{array}$ & $61,3 \%$ & $38,7 \%$ & $100 \%$ \\
$\begin{array}{l}\text { Ease of accessing } \\
\text { encyclopedias as a } \\
\text { learning resource }\end{array}$ & $63,9 \%$ & $36,1 \%$ & $100 \%$ \\
\hline
\end{tabular}

Source: Primary Data Processed, 2021

Based on the data in table 3 there are three indicators to find out students' experiences in using encyclopedia diversity as a learning resource. The first indicator is known that $79 \%$ of students have learned to use encyclopedia diversity as their learning source. The second indicator is that students answer $61.3 \%$ that if learning to use encyclopedia diversity is more fun and interesting compared to. In the third indicator of $63.9 \%$ students had no difficulty in accessing encyclopedia diversity as a learning resource.
Based on the needs analysis above, encyclopedia diversity making as an effort to improve students ' understanding of cultural diversity can be done because students learn with encyclopedia diversity more fun and attention. Learners are also more than happy to use encyclopedia diversity in learning than using textbooks, using student learning encyclopedia diversity as well as quickly understanding the material. Another factor in the degree of disunfamiliarity to the definition of cultural diversity and the understanding of cultural diversity of the learning provided by the teacher is still high.

\subsection{Design Stages}

At this stage the researchers designed the encyclopedia to be developed. Some of the steps used in this stage include: (1) Creating a flowchart. Flowchart creation is a flowchart to make it easier for researchers to understand the flow of creating encyclopedias, so that in its development there are clearly steps to be taken. (2) Create storyboards and scripts. Storyboarding is done specifically to design the parts that will be displayed in the encyclopedia of cultural diversity. In this step, the researchers compiled visual images of the diversity of cultures that will be used as content in the encyclopedia so that it will be clearly visible in the order of content from the beginning to the end of the encyclopedia.

\subsection{Development Stages}

This stage researchers create an encyclopedia based on the flow that has been compiled at the design stage. The tools used are some computer software such as corel draw, photoshop and canva. At this stage it combines images with text so that it becomes a complete unity in the media encyclopedia of cultural diversity. At this stage it is also evaluated about the materials and media that will be displayed in the encyclopedia based on input from material experts and media experts.

\subsection{Expert and media feasibility test results (expert judgment)}

The finished cultural diversity encyclopedia media is then validated by both the material and the content and the media itself so that the media is declared valid and worthy of use.

\section{a. Material expert validation}

Material experts provide an assessment of the content of the encyclopedia diversity material that has been compiled. Validated components are the accuracy of the material, the usefulness of the material, the use of terms, the depth of the material, the conceptual wrangling, the language used, encouraging student motivation to learn. The results of expert validation are presented in Diagram 1. 


\section{EXPERT VALIDATION RESULTS}

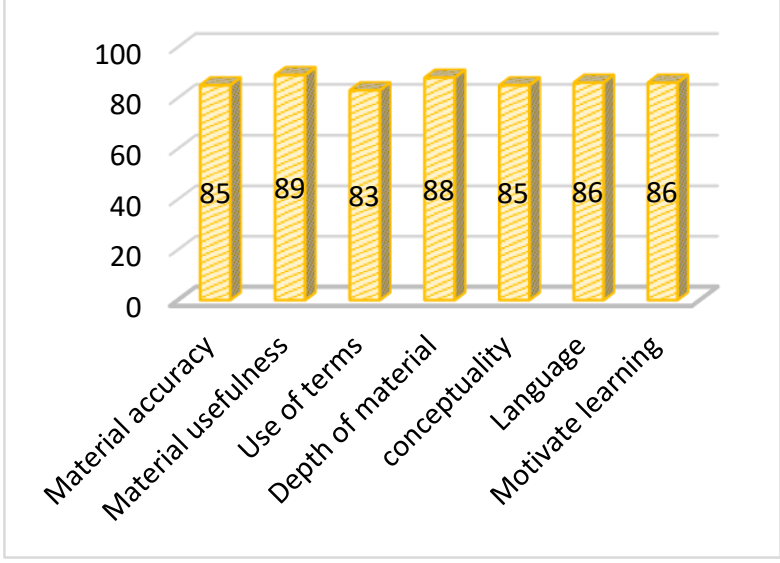

Figure 2. Source: Primary Data Processed, 2021

Based on the data, researchers are doing the average value of the material members validation results to determine the material to be eligible for the encyclopedia diversity. The Likert scale is used to create the eligibility category [19], as follows:

Table 4. Likert scale of material eligibility category

\begin{tabular}{cl}
\hline Interval & \multicolumn{1}{c}{ Category } \\
\hline $\mathbf{7 5 - 1 0 0}$ & Very feasible \\
$\mathbf{5 1 - 7 5}$ & Worth \\
$\mathbf{2 6 - 5 0}$ & Not feasible \\
$\mathbf{0 - 2 5}$ & Very Inadequate \\
\hline
\end{tabular}

Based on the assessment by expert validation in Diagram 1 above, each assessment indicator is calculated on average and then it is checked on a Likert scale in Table 4 above. The result is the average value of expert validation assessment is 86 . The results of the material in the encyclopedia diversity into the category is very feasible.

\section{b. Media expert validation}

Media experts validate the media encyclopedia of cultural diversity to determine whether or not it is used as a medium of learning. Some of the indicators used for judging are; technical quality, image quality, layout, image accuracy, ease of use, image resolution. The media validation results can be seen in Diagram 2 below:

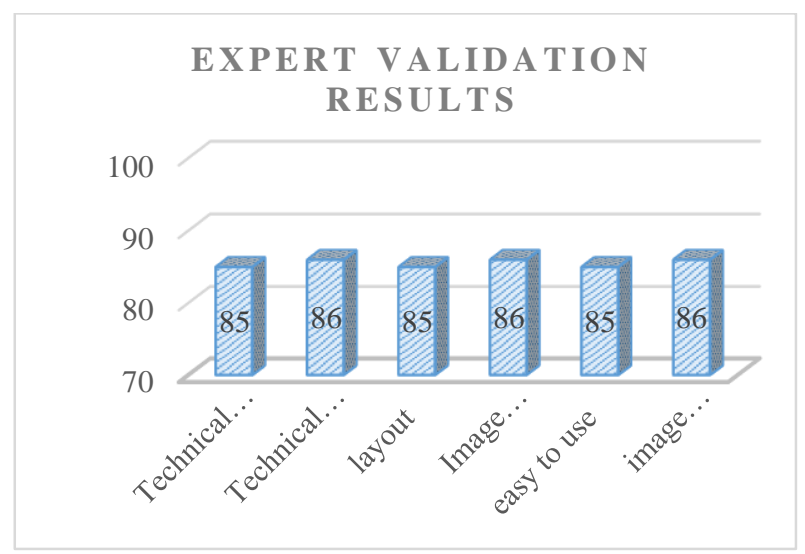

Figure 3. Source: Primary Data Processed, 2021
Based on the data, the researcher then averages the values of the results of the media expert's validation to determine the appropriateness of the media in encyclopedia diversity. Likert scale is used to make the eligibility category [20], as follows:

Table 5. Likert scale of material eligibility category

\begin{tabular}{cl}
\hline Interval & \multicolumn{1}{c}{ Category } \\
\hline $\mathbf{7 5 - 1 0 0}$ & Very feasible \\
$\mathbf{5 1 - 7 5}$ & Worth \\
$\mathbf{2 6 - 5 0}$ & Not feasible \\
$\mathbf{0 - 2 5}$ & Very Inadequate \\
\hline
\end{tabular}

Based on the assessment by expert validation in Diagram 2 above, each assessment indicator is calculated on average and then it is checked on a Likert scale in Table 5 above. The result is the average value of expert validation assessment is 85 . The result is that the media in encyclopedia diversity is in the very feasible category.

\section{CONCLUSION}

Based on the results of the needs analysis conducted on students shows that it is very necessary to create an encyclopedia of cultural diversity with the aim of improving students' understanding of the diversity of cultures owned by Indonesia. Students are happy and interested when learning using encyclopedias as opposed to learning to use textbooks. The encyclopedia's media is validated by two experts, material experts and media experts. The average value of the material expert validation assessment is 86 . In addition, the validation results of media experts obtained the results of the score with an average rating of 85 . Based on these components encyclopedias of cultural diversity are made of good quality and very worthy to be used as a medium of learning in schools. the development of encyclopedia learning media in the future can be more specific according to the subjects at school.

\section{AUTHORS' CONTRIBUTIONS}

The first author's contribution: designing and developing the Encyclopedia of Indonesian Culture; Second author: seeking expert validation; Third author: Analyzing results and input from media experts; Fourth, fifth and sixth authors: Conducted data collection for needs analysis. Contribution of all teams: Processing and compiling the results of research analysis into writing this article. 


\section{ACKNOWLEDGMENTS}

The author thanks the reviewer for the comments and valuable input provided in the writing of this article. The author also thanks the students especially at the Junior High School level in Central Java Province who have agreed to be respondents in this study.

\section{REFERENCES}

[1] Widayanti, W. 2018. 'Wawasan Kebangsaan Siswa Sekolah Menengah Atas dan Implikasinya Terhadap Ketahanan Pribadi Siswa'. Jurnal Ketahanan Nasional. Hal. 1-26.

[2] Undang-Undang Nomor 20 Tahun 2003 tentang Sistem Pendidikan Nasional.

[3] Lusi Rachmiazasi, Masduki, Paridjo dan Eem Kurniasih. 2019. Pengembangan Media Matematika Ensiklopedia Dengan Pendekatan Matematika Realistik di Sekolah Dasar. https://media.neliti.com/media/publications/91065ID-pengembangan-media-matematikaensikloped.pdf, diakses dan diunduh pada 10 April 2019 pukul 22:44 WIB, hlm. 40.

[4] Maryono, Ishartati, Peni Bektiningsih dan Supriyono,. 2019. Ensiklopedi Koleksi Rujukan dengan Informasi Mendasar dan Lengkap Soal Ilmu Pengetahuan.

http://masyono.staff.ugm.ac.id/2017/10/06/ensiklop edi-koleksi-rujukan-dengan-informasi-mendasardanlengkap-soal-ilmu-pengetahuan-oleh-maryonoishartati-peni-bektiningsih-supriyono/, diunduh pada tanggal 5 April 2019, pukul 11:15, hlm. 1

[5] Jules Nurhatmi , Muhammad Rusdi, dan Kamid. 2015. 'Pengembangan Ensiklopedia Digital Teknologi Listrik Berbasis Contextual Teaching and Learning (CTL)'. Jurnal: Edu-Sains Volume 4 No. 1.

[6] Maryono, Ishartati, Peni Bektiningsih dan Supriyono. 2019. Ensiklopedi. Koleksi Rujukan dengan Informasi Mendasar dan Lengkap Soal Ilmu Pengetahuan., hlm. 1-9.

[7] https://www.rtu.edu.ph/library\%20new\%20home\% 20page/Encylopedia\%20module.pdf 6:37 wib 31 maret 2019.

[8] Djunaedi dan Rika Amalia Permatasari. 2018. "Pengembangan Ensiklopedia Kelompok Tenaga Kerja Hukum dalam layanan Bimbingan Klasika di SMA Negeri 5 Bogor”, Insight: Jurnal Bimbingan dan Konseling 7 (2). hlm. 177-178.

[9] Andi Ikhsan, Sulaiman, dan Ruslan. 2017. 'Pemanfaatan Lingkungan Sekolah sebagai Sumber
Belajar di SD Negeri 2 Teunom Aceh Jaya. Jurnal: Ilmiah Pendidikan Guru Sekolah Dasar FKIP Unsyia. Volume 2 Nomor 1, 1-11.

[10] Ary H. Gunawan. 2000. Sosiologi Pendidikan Suatu Analisis Sosiologi tentang Pelbagai Problem Pendidikan. Jakarta Rineka Cipta. h. 16.

[11] Selo Soemardjan dan Soelaeman Soemardi. 1964. Setangkai Bunga Sosiologi. Jakarta: Yayasan Badan Penerbit Fakultas Ekonomi UI. h. 115.

[12] Departemen Pendidikan Nasional, Kamus Besar Bahasa Indonesia(KBBI). 2000. Edisi ke-3. Jakarta: Balai Pustaka. h. 169.

[13] Soekanto, Soerjono. 2009. Sosiologi suatu Pengantar. Jakarta: Rajawali Pers. h. 150-151.

[14] Ki Hajar, Dewantara. 1994. Kebudayaan. Yogyakarta: Penerbit Majelis Luhur Persatuan Tamansiswa.

[15] Pelly, Usman. 1994. Teori-Teori Ilmu Sosial Budaya. Departemen Pendidikan dan Kebudayaan, Jakarta: Depdiknas.

[16] Koentjaraningrat. 2002. Pengantar Ilmu Antropologi. Jakarta: Rineka Cipta.

[17] Sumaatmadja, Nursid. 2000. Manusia dalam Konteks Sosial Budaya dan Lingkungan Hidup. Bandung: Alfabeta.

[18] Daryanto. 2011. Model Pembelajaran. Bandung: PT Sarana Tutorial Nurani Sejahtera.

[19] Arsyad, Azhar. 2011. Media Pembelajaran. Jakarta: PT. Raja Grafindo Persada.

[20] Borg dan Gall. 1985. Educational Research, An Introduction. New York and London. Longman Inc. 